\title{
The Lame Rosse geosite (Northern Apennines, Italy): a glance at its formation processes
}

\author{
Ivan Martini ${ }^{1}\left[\right.$ Giulia Pagliaricci $^{1}$
}

The COVID-19 pandemic has brought many Italians closer to the Nature, with a growing interest in trekking and related activities. To maintain this renewed interest in our natural environment, it will be important to further increase the awareness of visitors, also thanks to an accurate but, at the same time, simple and understandable scientific divulgation of the main features of most important geosites.

The "Lame Rosse" geosite (Fig. 1) has seen an incredible increase in visitors in recent years (the hashtag "\#lamerosse" on Instagram indexes over a $16.5 \mathrm{k}$ posts in November 2021). Despite its fame, few geological information is available for the site. The aim of this note (derived from the BSc thesis of one of the authors, GP) is to provide a brief sedimentological and stratigraphic characterization of one of the most fascinating geosites of the Italian peninsula.

The geosite (Fig. 1) consists of a spectacular series of gullies incised in a reddish sedimentary succession (about $60 \mathrm{~m}$ thick) mainly made of debris and sand-sized materials. The succession fills a narrow valley (about $200 \mathrm{~m}$ wide) dug in the marine-pelagic formations of the Umbro-Marchigiana succession (cf. Coccioni 1996). The peculiar reddish color of the debris derive by the color of the formation from which debris derive, i.e., a reddish pelagic limestone ("Scaglia Rossa" Fm).

Strata are mainly clinostratified toward SW with inclinations ranging from $10^{\circ}$ to $25^{\circ}$, with uncommon lobe-shaped bodies inclined toward SE. Four main depositional facies have been recognized (in order of abundance: rockfall, debrisflow, grainflow and waterflow deposits sensu Blikra and Nemec, 1998), whose association resembles those identified by Blikra and Nemec (1998) and Nemec and Kazanci (1999) as typical for colluvial deposits. The combined sedimentological and stratigraphic features allow to interpret the sedimentary succession exposed at the Lame Rosse as the expression of coalescent colluvial cones, most of which are prograding from NE to SW.

The succession was probably deposited during a cool Quaternary phase when climatic conditions promoted debris production and reduced soil development. Subsequently, the erosive action of channelized and/or runoff waters led to the current morphological configuration. The erosion may have been increased due to deforestation and pastoral activities that led to the reduction of surface soil and its protective effect (Coltorti 1991).

Ivan Martini

ivan.martini@unisi.it

1 Dipartimento Di Scienze Fisiche, della Terra e dell'Ambiente, Università Di Siena, via Laterina 8, 53100 Siena, Italy 


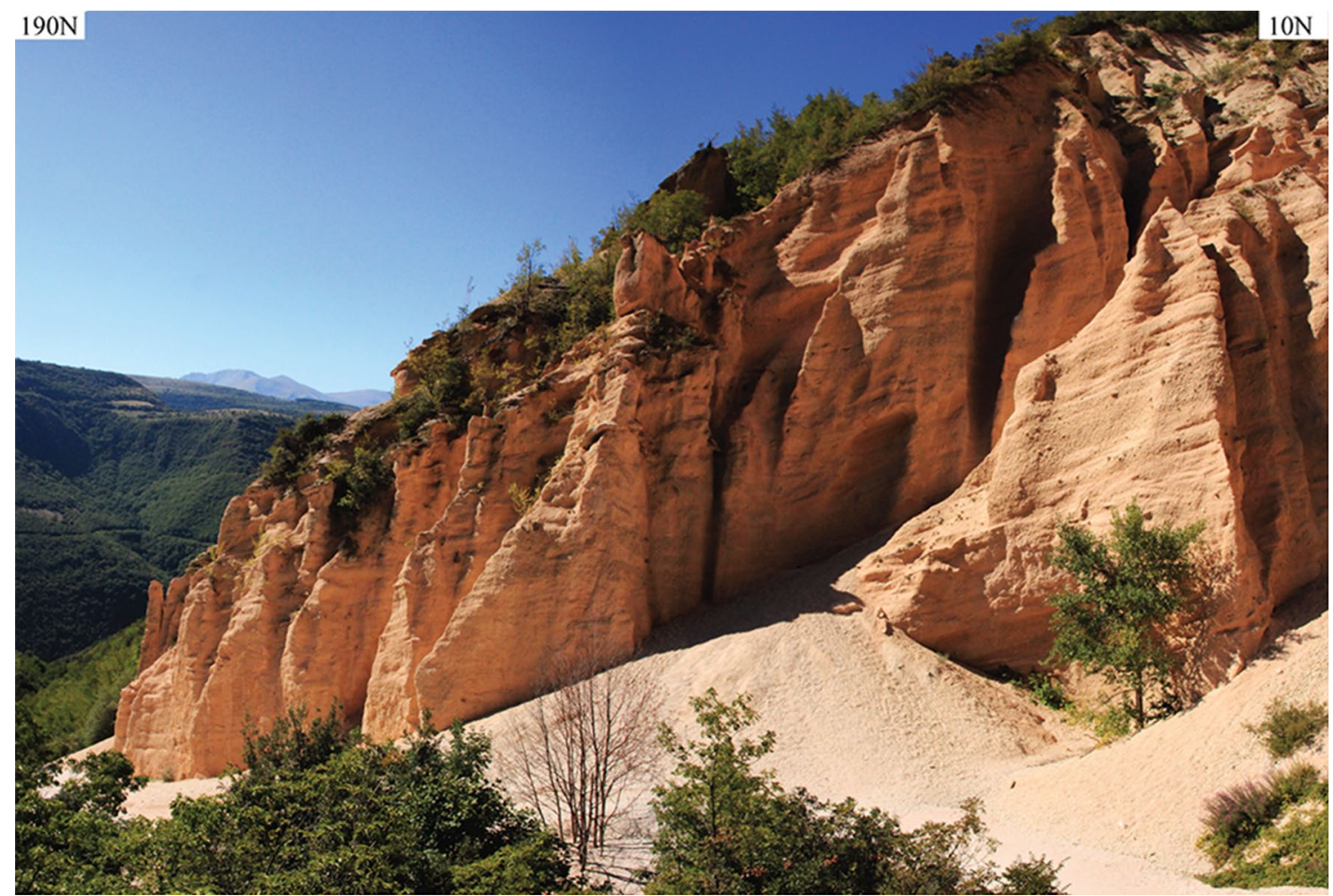

Fig. 1 Panoramic view of the "Lame Rosse" geosite. The tree close to the outcrop is about $10 \mathrm{~m}$ high

Acknowledgements The Municipality of Fiastra (Macerata) and the Parco Nazionale dei Monti Sibillini are thanked for providing us with permits to do the study. Dr. Geol. Maurizio Piccini is thanked for the valuable information on the site.

\section{References}

Blikra LH, Nemec W (1998) Postglacial colluvium in western Norway: depositional processes, facies and palaeoclimatic record. Sedimentology 45(5):909-960
Coccioni R (1996) The cretaceous of the Umbria-Marche Apennines (central Italy). In: Wiedmann J (ed) Symposium cretaceous stratigraphy, paleobiology and paleobiogeography. Tubingen, Germany, pp 129-136

Coltorti M (1991) Modificazioni morfologiche oloceniche nelle piane alluvionali marchigiane: alcuni esempi nei fiumi Misa, Cesano e Musone. Geogr Fis Din Quat 14(1):73-86

Nemec W, Kazanci N (1999) Quaternary colluvium in west-central Anatolia: sedimentary facies and palaeoclimatic significance. Sedimentology 46(1):139-170 